\title{
Diagnosis and Treatment of Primary Cutaneous B-Cell Lymphomas: State of the Art and Perspectives
}

\author{
Maëlle Dumont ${ }^{1,2,3} \mathbb{C}^{-}$, Maxime Battistella ${ }^{2,3,4}$, Caroline Ram-Wolff ${ }^{1}$, Martine Bagot ${ }^{1,2,3, *}$ \\ and Adèle de Masson 1,2,3,t \\ 1 Department of Dermatology, APHP, Saint-Louis Hospital, F-75010 Paris, France; \\ maelledumont@gmail.com (M.D.); caroline.ram-wolff@aphp.fr (C.R.-W.); adele.demasson@aphp.fr (A.d.M.) \\ 2 INSERM U976, Human Immunology, Pathophysiology and Immunotherapy, Institut de Recherche \\ Saint-Louis, F-75010 Paris, France; maxime.battistella@aphp.fr \\ 3 Faculty of Medicine, Université de Paris (Paris University), F-75010 Paris, France \\ 4 Pathology, APHP, Saint-Louis Hospital, F-75010 Paris, France \\ * Correspondence: martine.bagot@aphp.fr; Tel.: +33-1-53-72-20-93; Fax: +33-1-42-49-40-38 \\ + Share last authorship.
}

Received: 17 May 2020; Accepted: 4 June 2020; Published: 8 June 2020

\begin{abstract}
Primary cutaneous B-cell lymphomas are rare entities that develop primarily in the skin. They constitute a heterogeneous group that represents around a quarter of primary cutaneous lymphomas. The 2018 update of the World Health Organization-European Organization for Research and Treatment of Cancer (WHO-EORTC) classification differentiates primary cutaneous marginal zone lymphoma and primary cutaneous follicle center lymphoma with an indolent course from primary cutaneous diffuse large B-cell lymphoma, leg type with an aggressive behavior. The broad spectrum of clinical presentations and the disease course marked by frequent relapses are diagnostic and therapeutic challenges. The classification of these diseases has been refined in recent years, which allows to better define their immunopathogenesis and specific management. In the present article, we review the main clinico-biological characteristics and the current therapeutic options of these three main subsets. Based on the recent therapeutic advances in nodal B-cell lymphomas, we focus on the development of novel treatment options applicable to primary cutaneous B-cell lymphomas, including targeted therapies, combination treatments and immunotherapeutic approaches, and cover basic, translational and clinical aspects aiming to improve the treatment of cutaneous B-cell lymphomas.
\end{abstract}

Keywords: cutaneous B-cell lymphomas; lymphoid malignancies; B-cells; lymphocytes; skin; lymphomas; B-cell lymphomas; review

\section{Introduction}

Primary cutaneous B-cell lymphomas (PCBCL) represent approximately 20 to $25 \%$ of all primary cutaneous lymphomas (PCL) [1,2]. The incidence of these rare entities is estimated to be $<1$ per 100,000 people/year and increases with age [1-3].

By definition, PCBCL are present in the skin with no evidence of extracutaneous disease at the time of diagnosis. They belong to the group of lymphoid malignancies, which are currently defined according to the 2016 revision of the WHO classification of lymphoid neoplasms [4]. The World Health Organization-European Organization for Research and Treatment of Cancer (WHO-EORTC) classification has recently been updated to best define this heterogeneous group of primary cutaneous lymphomas [1,2]. In the 2018 update of the WHO-EORTC classification [2], the three most common entities are primary cutaneous marginal zone lymphoma (PCMZL), primary cutaneous follicle center 
lymphoma (PCFCL) and primary cutaneous diffuse large B-cell lymphoma, leg type (PCDLBCL, LT). PCMZL and PCFCL have an indolent behavior while PCDLBCL, LT is an aggressive subset.

Intravascular large B-cell lymphoma (IVLBCL) is an extremely rare entity, most often associated with extracutaneous involvement (central nervous system, lung) that can also present with skin-limited disease. Included as a new provisional entity in the 2016 revision of the WHO-classification [4] and in the updated 2018 classification [2], $\mathrm{EBV}^{+}$mucocutaneous ulcer (EBVMCU) is also very rare and defined as an ulceration of the skin, oropharyngeal mucosa, or gastrointestinal tract in immunocompromised patients (such as elderly patients and/or patients treated with methotrexate, cyclosporine, azathioprine, or tumor necrosis factor alpha inhibitors).

The staging of PCBCL has been defined by the WHO/EORTC [5] and a CT scan at least is recommended at baseline to rule out systemic involvement.

Optimal management of PCBCL requires multi-disciplinary collaboration between dermatologists, hematologists, pathologists and radiation oncologists. Guidelines for the treatment of PCBCL have been published by the EORTC [6].

This review describes the epidemiological, clinical, histopathological, cytogenetic and molecular features of each of the three most frequent PCBCL subtypes and focuses on the current therapeutic options and future developments in the management of PCBCL.

\section{Indolent PCBCL}

\subsection{Primary Cutaneous Marginal Zone Lymphoma}

\subsubsection{Epidemiology/Prognosis}

PCMZL accounts for $9 \%$ of the PCL and is the second most common PCBCL. The five-year survival rate is around $99 \%$ [2]. It typically affects medium-aged adults although pediatric cases have also been reported [7].

\subsubsection{Diagnosis}

PCMZL usually presents with erythematous to violaceous papules, plaques, nodules or tumors (Figure 1A), sometimes infiltrated but ulceration is atypical. Peri-lesional annular or diffuse erythema is possible [8]. Solitary or multifocal, the lesions are localized preferentially on the trunk or the upper extremities. The lesions can regress spontaneously and rarely give way to anetoderma [9]. PCMZL manifesting as AL amyloidoma of the skin, without systemic amyloidosis, has also been reported [10]. Cutaneous relapses occur in half of the cases but extracutaneous spread is very uncommon [11], as well as transformation to high-grade lymphoma [12].
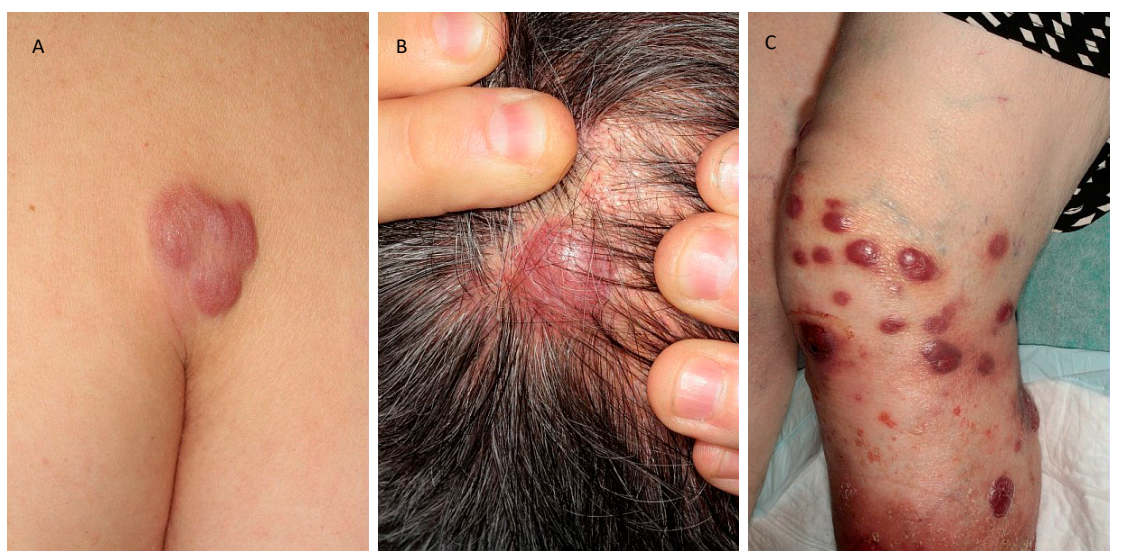

Figure 1. Clinical presentations of the three main subsets of primary cutaneous B-cell lymphomas. (A) Primary cutaneous marginal zone lymphoma; (B) primary cutaneous follicle center lymphoma; (C) primary cutaneous diffuse large B-cell lymphoma. 


\subsubsection{Histology}

The infiltrate is made of small lymphocytes, small centrocyte-like B-cells, lymphoplasmacytoid cells, plasma cells and also reactive T cells (Figure 2a). Eosinophils are observed in about $25 \%$ of the cases [13]. Scattered follicles with reactive germinal centers (GC) are surrounded by marginal zone B cells with irregular nucleus, inconspicuous nucleoli and abundant pale cytoplasm [1].

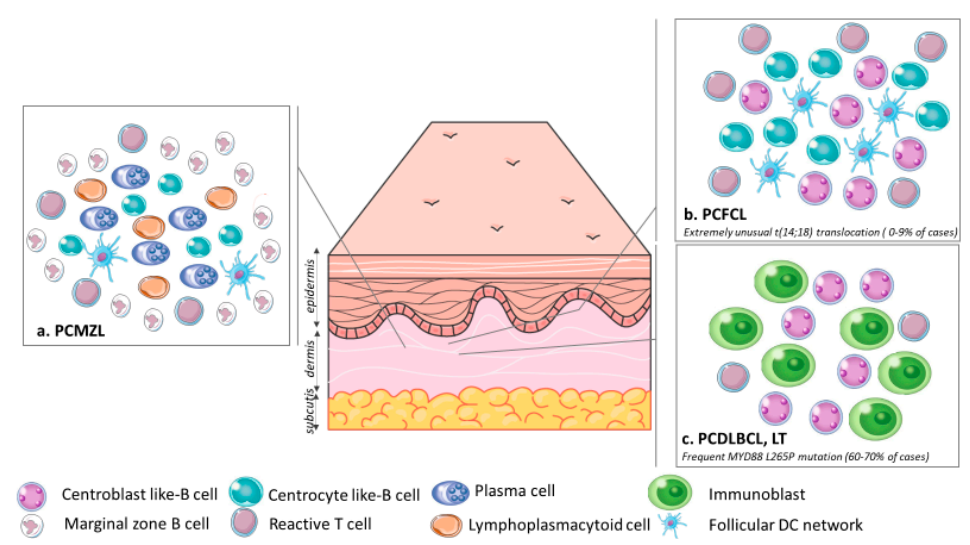

Figure 2. Organization of the tumor cells and microenvironment in (a). PCMZL: Infiltrate made of small centrocyte-like B-cells, lymphoplasmacytoid cells, plasma cells and reactive T cells admixed with a FDC network surrounded by marginal zone B cells; (b). PCFCL: Infiltrate made of centrocytes and centroblasts often with a FDC network and scattered reactive T cells; (c). PCDLBCL, LT: A monomorphic population of large atypical cells ressembling centroblasts and immunoblasts. The $t(14 ; 18)$ translocation is extremely rare in PCFCL, unlike in primary nodal follicular lymphoma. The PCDLBCL, LT is characterized by frequent MYD88 L265P mutations, which helps discriminate PCDLBCL, LT from PCFCL with large cells, in which the MYD88 L265P mutation is absent. Abbreviations: PCMZL, primary cutaneous marginal zone lymphoma; PCFCL, primary cutaneous follicle center lymphoma; PCDLBCL, LT, primary cutaneous diffuse large B-cell lymphoma, leg type; DC, dendritic cell.

\subsubsection{Immunohistochemistry, Cytogenetic and Molecular Features}

Two types of PCMZL have been described [14,15]. Most PCMZL express class-switched immunoglobulins (IgG and more rarely $\operatorname{IgA}$ or IgE) with a predominance of $\mathrm{T}$ cells in a T-cell helper type 2 environment. Several cases with IgG4 expression have been reported [16,17]. The second subset of PCMZL shows a diffuse proliferation or large nodules of B cells expressing IgM and often CXCR3 [2].

Neoplastic cells are CD20 ${ }^{+}, \mathrm{CD} 79 \mathrm{a}^{+}$and Bcl-2 ${ }^{+}$and negative for Bcl-6 and CD10 [8]. Plasma cells express CD138 and CD79a and have a monotypic expression of the kappa or lambda light chain. Immunophenotyping helps distinguish the class-switched immunoglobulins and the IgM-positive subset. Cases with class-switched immunoglobulins often have more prominent $\mathrm{CD} 21^{+}$follicular dendritic cell (FDC) networks and lack CXCR3 expression, unlike IgM-positive cases [14].

Recurrent alterations of the FAS gene have been recently highlighted, suggesting that a downregulation of apoptosis could be a mechanism explaining the indolent behavior of PCMZL [18].

Chromosomal abnormalities are uncommon in PCMZL. Rare $\mathrm{t}(14 ; 18), \mathrm{t}(3 ; 14), \mathrm{t}(11 ; 18)$ or trisomy 3 or 18 have been reported, but if present, a systemic entity should be closely worked-up [19].

\subsubsection{Etiology}

Etiology remains unknown. The main hypothesis is a chronic antigen stimulation. Different associations have been reported to date: Borrelia burgdorferi in European cases [20], Helicobacter pylori colonization of the stomach [21], influenza or viral hepatitis A vaccination, arthropod bites, traumatic injuries, tattoos [22-24]. Associations with gastrointestinal disorders and autoimmune diseases have been reported in PCMZL [24]. 


\subsection{Primary Cutaneous Follicle Center Lymphoma}

\subsubsection{Epidemiology/Prognosis}

PCFCL are the most common PCBCL, representing about $60 \%$ of the cases. The five-year survival rate is around $95 \%$ although localization on the legs has been associated with a poorer prognosis. PCFCL typically affects middle-aged adults. Relapses occur in roughly half of the cases but extracutaneous dissemination is rare $[2,3,25]$.

\subsubsection{Diagnosis}

Clinical features are firm erythematous to purple macules, papules, plaques or tumors (Figure 1B). Often solitary, the lesions are mainly localized on the head and the trunk. Spontaneous regression is rare, and the lesions tend to increase in size without treatment. Some cases present as alopecic patches of the scalp [26].

\subsubsection{Histology}

The neoplastic infiltrate presents with a follicular, follicular and diffuse, or diffuse growth pattern. The epidermis is spared with a grenz zone. Tumor cells are made of centrocytes, most often with small nuclei, and centroblasts. An FDC network and reactive T cells are often seen (Figure 2b). There are variants with large centrocytic cells with a clear cytoplasm, cases with spindle tumor cells, and also cases with Hodgkin and Reed Sternberg like cells [27-29]. The staging system used for nodal follicular lymphoma does not have prognostic value in PCFCL [30].

\subsubsection{Immunohistochemistry, Cytogenetic and Molecular Features}

Neoplastic B cells are CD19 ${ }^{+}, \mathrm{CD}_{20}{ }^{+}, \mathrm{CD} \mathrm{Ca}^{+}, \mathrm{PAX}^{+}, \mathrm{IgM}^{-}, \mathrm{Bcl}-6^{+}$and most often bcl-2 ${ }^{-}$. Coexpression of Bcl-2 and CD10 should lead to rule out a primary nodal follicular lymphoma with secondary skin involvement [31,32]. Post germinal center (GC) markers IRF4/MUM1 and FOXP1 are negative, unlike in DLBCL, LT. The residual FDC network expresses CD21 and CD23.

The MYD88 L265P mutation is absent (helping the distinction between DLBCL, LT and PCFCL with large cells) and the $t(14 ; 18)$ translocation is extremely rare (unlike in primary nodal follicular lymphoma).

\subsection{Treatment of Indolent Lymphoma}

In localized disease, first-line therapies are usually local radiation or surgical excision. The effectiveness of antibiotics in the case of a Borrelia burgdorferi positive serology is still controversial [22,33,34]. A wait-and-see attitude is considered possible in the EORTC [6] and the National Comprehensive Cancer Network (NCCN) guidelines [35]. The expectant management could be distressing for patients with PCBCL given the impact of the disease on health-related quality of life (HRQoL) [36].

Complete response (CR) rate is close to $100 \%$ with local radiation, although relapses and acute adverse events (AE) occur in almost half of the cases [37]. Retrospective cohorts help define the optimal dose to reduce toxicity and maintain a high response rate. No significant difference between very low dose (4-8 Gy) and standard dose (>24 Gy) has been found by Goyal et al. [38] but the response rate was significantly lower in the very low dose group (4 Gy) versus standard dose (>24 Gy, median $40 \mathrm{~Gy}$ ) in a recent study on PCMZL and PCFCL [39]. The European Society for Medical Oncology (ESMO) guidelines recommend a standard dose of 24 to $30 \mathrm{~Gy}$ for localized disease and a low dose of $4 \mathrm{~Gy}$ for the palliative treatment of disseminated disease [40].

A retrospective study on indolent PCBCL found no significant difference in terms of five-year disease free survival (DFS, 96\%) between high-dose (30 to $40 \mathrm{~Gy}$ ) radiation and surgery after an average follow-up of 3.6 years [41]. 
Disseminated lesions may be treated with intravenous rituximab, an anti-CD20 monoclonal antibody. According to a literature review by Morales et al., durations of response ranged from 4 to 39 months with a median of 14 months for PCFCL and 9 months for PCMZL. CR rate was higher for PCFCL (77\%) than for PCMZL (43\%) [42]. However, patients were treated with variable numbers of infusions.

When lesions are difficult to treat by radiotherapy or surgery, such as the face and the scalp, treatment with intralesional rituximab has been considered. Indeed, the CR rate ranged from $83 \%$ to $89 \%$ [6]. In a recent study, the favorable clinical outcome was correlated with AEs such as marked flu-like symptoms [43]. In a small retrospective study, Kerl et al. observed that in two-thirds of patients with relapses, new lesions occurred at another site [44]. There was no recurrence on the injected lesions. Response rates were quite similar between PCMZL and PCFCL treated with intralesional rituximab [44,45].

In disseminated disease, another option is subcutaneous interferon-alpha. In a retrospective study, the overall response rate (ORR) was $66.7 \%$ with a median duration of response of 15.5 months, but the relapse rate was around $90 \%$ after 40 months of median follow-up [46].

Interferon-alpha (IFN- $\alpha$ ) has also been used intralesionally in PCMZL. Eight patients received intralesional injections of three million IU, three times per week. All patients reached a CR after a median of eight weeks, two patients relapsed locally, and experienced a secondary CR after treatment with IFN- $\alpha$. No extracutaneous relapses were reported and side effects were generally mild [47].

To increase the efficacy of immunotherapy, antibodies have been combined with radioisotopes. Yttrium-90 ibritumomab tiuxetan $(\mathrm{IbT})$ is an anti-CD20-antibody conjugated with an isotope that delivers the cytotoxic effects of radiation to $\mathrm{CD} 20$-expressing $\mathrm{B}$ cells. In a retrospective cohort of 10 patients including 8 PCFCL and 2 PCDLBCL, LT, the ORR was 100\% with a median time to relapse of 12 months [48]. IbT was approved by the Food and Drug Administration (FDA) for systemic B-cell lymphomas (BCLs) but has not been further explored in PCBCL. Despite this efficacy, application of IbT has been limited by concerns about treatment-related myeloid neoplasms (including myelodysplastic syndrome and acute myeloid leukemia) as a consequence of diffuse irradiation of the bone marrow [49].

Recently rituximab has also been combined with lenalidomide. A phase III study of lenalidomide plus rituximab versus placebo plus rituximab in relapsed or refractory indolent lymphomas showed encouraging results with a significantly increased PFS (hazard ratio of $0.46,95 \% \mathrm{CI}, 0.34$ to 0.62 ) [50].

Other immunotherapeutic approaches include intralesional adenovirus-interferon gamma (TG1042), a non-replicating human adenovirus vector allowing the intracellular transfer of human interferon (IFN)-gamma cDNA. IFN-gamma gene delivery induces an immune response to lymphoma tumor-antigens resulting in the regression of injected but also noninjected lesions. A phase 1 study on nine patients showed three CR and two partial responses (PR) [51]. Three cases of multilesional CBCL among 21 patients were treated in a phase 2 clinical trial: one local CR, one local PR and one global response with disappearance of noninjected distant lesions were observed [52]. The results of the last clinical trial on relapsing PCBCL including six PCFCL, six PCMZL and one PCDLBCL other than leg type, were published in 2014 . The ORR was $85 \%$ with a majority of CR. Median time to progression was 23.5 months. Side effects were mild to moderate with reactions at the injection site or flu-like syndromes [53].

Topical imiquimod monotherapy has been recently studied in CBCL in a retrospective monocentric cohort in the United States. Sixteen patients with indolent CBCL (T1aN0M0 to T3aN0M0) were treated with imiquimod $5 \%$ cream. The ORR was $62 \%$ including $31 \%$ of complete and $31 \%$ of partial responses with a median duration of treatment of 4.6 months (range 1.4 to 9.8 months). All CR occurred in T1a lesions. Histology type was not predictive of response. The only AE was local irritation. The relapse rate was not precise [54].

\section{Aggressive PCBCL}

Primary cutaneous diffuse large B-cell lymphoma, leg type 


\subsection{Epidemiology/Prognosis}

PCDLBCL, LT represents $10-20 \%$ of PCL. It is an aggressive lymphoma with at least $10 \%$ of extracutaneous spread. Affecting mainly elderly women, the disease-specific-survival is around $56 \%[2,3]$.

\subsection{Diagnosis}

Lesions are generally localized on one or both legs, but other sites are involved in 10-15\% of the cases. Painful, sometimes necrotic, the nodules or plaques rapidly grow into tumors that may be possibly ulcerated (Figure 1C). Solitary or more often multiple lesions can be observed $[55,56]$.

\subsection{Histology}

The infiltrate is diffuse in the dermis and the subcutis. The epidermis is spared with a grenz zone, but ulceration is possible. A monomorphic population of large atypical cells resembling centroblasts in confluent sheets and sometimes immunoblasts with round cells are observed, mitotic figures are frequent (Figure 2c). Perivascular, reactive T cells are less common than in other PCBCL $[57,58]$.

\subsection{Immunohistochemistry, Cytogenetic and Molecular Features}

B cell lineage markers help identify tumor cells: $\mathrm{CD} 20^{+}, \mathrm{CD} 9 \mathrm{a}^{+}, \mathrm{PAX}^{+}$with variable cytoplasmic IgM. Expression of Bcl-2 is strong, Bcl- 6 variable and CD10 negative. In $75 \%$ of the cases, cMYC expression is present. When present, the double expression of MYC and Bcl-2 is evocative [59]. The expression of post GC markers IRF4/MUM1 and FOXP1 is also helpful for diagnosis. Proliferation is high with Ki67 around 60 to $90 \%$ [2,57,60]. Somatic mutations similar to the ABC (activated B cell)-type DLBCL have been observed by massive parallel sequencing [22,61]: mutations in the NFkB pathway such as the L265P MYD88 mutation (60-70\% of the cases), TNFAIP3/A20, CD79B and CARD11 [62-64]. The MYD88 mutation is a biomarker for diagnosis because it is absent in other primary cutaneous B-cell lymphomas, especially PCFCL with large centrocytes [59]. $c M Y C$ rearrangements and inactivation of $C D K N 2 a$ by either deletion or promoter hypermethylation also participate in the pathophysiology of PCDLBCL, LT [64-67] and are associated with a poor prognosis [59,64,66]. More recently, Zhou et al. observed that $40 \%$ of 19 cases of PCDLBCL, LT had recurrent genetic alterations in PD-L1/PD-L2 [68].

\subsection{Tumor Microenvironment}

Mitteldorf et al. analyzed the tumor microenvironment in biopsy specimens of 16 PCDLBCL. They noticed $63 \%$ of $\mathrm{CD}_{3} 3^{+}$myeloid-derived suppressor cells (MDSCs) with PD-L1 coexpression but also immunosuppressive $\mathrm{CD}_{163^{+}} \mathrm{M} 2$ macrophages. Finally, in all the cases, tumor cells expressed membrane-bound PD-L1 suggesting a mechanism to escape immune surveillance [69].

Menguy et al. confirmed PD-L1 expression by numerous immune cells, characterized as $\mathrm{CD}_{163}{ }^{+}$ M2 macrophages, in the tumor microenvironment of PCDLBCL, LT [70]. On the other side, Felcht et al. found that CD4 and FOXP3 expression as well as the CD4/FOXP3 ratio were significantly decreased in PCLBCL, LT as compared to PCBCL of indolent behavior, suggesting that regulatory T cells may inhibit tumor progression in PCBCLs [71].

\subsection{Treatment}

PCDLBCL, LT is an aggressive lymphoma affecting elderly people and its management is thus challenging.

Local treatment is used as palliative treatment in patients unable to stand systemic treatments, or in combination with systemic treatments. Surgical excision of a single lesion, or local radiation therapy can help relieve the symptoms although the effect is mostly temporary [72].

Currently, first line treatment is rituximab and combination chemotherapy, most commonly cyclophosphamide, doxorubicine, vincristine and prednisone (CHOP)-like regimens if the general 
condition of the patient allows it $[6,40]$. In a large retrospective study evaluating survival and prognosis factors, Grange et al. showed that the combination of rituximab to polychemotherapy has significantly improved the prognosis of PCDLBCL, LT [56]. The prognosis may be further improved using age-adapted rituximab-polychemotherapy [73]. Based on favorable data of pegylated liposomal doxorubicine in primary cutaneous T cell lymphoma, five patients including four PCDLBCL, LT were treated in a phase II pilot clinical trial with good results. All the patients achieved CR after a median delay of three months, two relapsed. Side effects were generally mild, with only one case of grade 3 neutropenia. There was no need to decrease the doses or to interrupt the treatment [74]. A multicenter phase II clinical trial studied the association of pegylated liposomal doxorubicine and rituximab in 12 patients including three PCDLBCL, LT. Seven had relapsed disease, one-fourth had received radiotherapy as prior treatment. With a median follow-up of 56 months, the ORR of PCDLBCL, LT patients was $66 \%$ including $33 \%$ of complete and $33 \%$ of partial responses. The median time to best response was two months (ranging from one to four months) with a good safety profile: only grade 2 AEs were observed (neutropenia and palmar-plantar erythrodysesthesia) [75]. New combination treatments with rituximab need to be explored.

Rituximab combined with bendamustine, an intravenous alkylating agent, has been tried in DLBCL [76]. Retrospective data suggest that it may be a valuable treatment option in older patients [77]. A recent study reports the case of an 87-year-old woman with large nodules on the legs treated with rituximab plus bendamustine. Unfortunately the tumors progressed after two courses of treatment [78].

The preferential localization on the legs has led to the use of isolated limb perfusion with melphalan in a case report of a 61-year-old woman with relapsed disease. The response was complete and lasted for eight months with only mild lymphedema that resolved with regular compression massages [79].

PCDLBCL, LT have the phenotype and gene expression profile of ABC-type DLBCL and the ESMO guidelines recommend that they should be treated as other ABC-type DLBCLs [22,40,62]. Moreover, the presence of genetic abnormalities of the B-cell receptor pathway (such as CD79B) has been associated with a poor prognosis after first line treatment with R-CHOP [80] and could suggest the use of Bruton tyrosine kinase (BTK) inhibitors such as ibrutinib in the absence of associated CARD11 or PIM1 mutations that are associated with ibrutinib resistance [81,82]. BTK is an important signaling molecule of the B-cell receptor (BCR) signaling pathway. One study reported an excellent outcome with ibrutinib in a refractory PCDLBCL, LT after five therapeutic lines [83].

Multiple genetic abnormalities activating the NF- $\mathrm{BB}$ pathway support the use of lenalidomide, which targets the interferon regulatory factor (IRF)-4. In a multicenter, single-arm, phase II trial, Beylot-Barry et al. followed 19 patients with relapsing or refractory PCDLBCL, LT. The ORR was $26.3 \%$ and reduced doses tended to be associated with higher six-month ORR and progression-free survival (PFS). Five patients discontinued treatment because of hematologic, septic, cardiac or cutaneous toxicity. The MYD88 mutation was not associated with a higher response rate, which is consistent with the fact that the MYD88 mutation is associated with a poorer prognosis [59,64,84].

The discovery of a subset of PCDLBCL, LT with recurrent genetic alterations in PD-L1/PD-L2 [69] suggests that the use of immune checkpoint inhibitors could be explored. Di Raimondo reported the case of an 85-year-old man with a three-year history of DLBCL, LT refractory to three prior therapies. $\mathrm{CR}$ was observed with the association of rituximab, lenalidomide and pembrolizumab. Introduction of the treatments was sequential (rituximab first, then lenalidomide and finally pembrolizumab) with the aim to enhance the efficacy of the checkpoint inhibitor [85].

\section{Therapeutic Perspectives in Indolent and Aggressive PCBCL}

The use of novel agents developed in nodal BCL is being increasingly considered in PCBCL (Table 1). 
Table 1. Efficacy and safety of selected novel therapies in B-cell lymphomas.

\begin{tabular}{|c|c|c|c|c|c|c|c|c|c|c|c|}
\hline Target & Treatment & Phase & $\begin{array}{c}\mathrm{Nb} \text { of } \\
\mathrm{pts}\end{array}$ & Pathology & ORR (\%) & CR $(\%)$ & $\begin{array}{c}\text { Median } \\
\text { PFS (mo) }\end{array}$ & $\begin{array}{l}\text { DOR } \\
\text { (mo) }\end{array}$ & $\begin{array}{l}\text { Median f-u } \\
\quad(\text { mo })\end{array}$ & Adverse Effects & Reference \\
\hline \multicolumn{12}{|l|}{ Small Molecule Inhibitors } \\
\hline BTK & Ibrutinib & case report & 1 & PCDLBCL, LT & 100 & 100 & ND & 18 & ND & \multirow{5}{*}{$\begin{array}{c}\text { ND } \\
\text { headache, gd } 3 \text { hematologic } \\
\text { events, pneumonia } \\
\text { neutropenia, subcutaneous } \\
\text { hemorrhage } \\
\text { diarrhea, nausea, neutropenia } \\
\text { urine color change, prolonged } \\
\text { OTc interval }\end{array}$} & Gupta et al. \\
\hline BTK & Acalabrutinib & II & 124 & $\mathrm{R} / \mathrm{R} \mathrm{MCL}$ & 81 & 40 & $\mathrm{NR}$ & $\mathrm{NR}$ & 15,2 & & Wang et al. \\
\hline BTK & Zanubrutinib & I & 78 & $\mathrm{R} / \mathrm{R}$ CLL/SLL & 96.2 & 2.6 & NR & ND & 13.7 & & Tam et al. \\
\hline РІ3К $\delta$ & Parsaclisib & $\mathrm{I} / \mathrm{II}$ & 72 & R/R NHL & 20 to 100 & 0 to 44 & ND & 4.4 to 13.5 & ND & & Forero Torres et al. \\
\hline РКС $\beta$ & Enzastaurin & III & 758 & DLBCL & 80 & $\mathrm{ND}$ & ND & ND & 48 & & Crump et al. \\
\hline TLRs $7,8,9$ & IMO-8400 & $\mathrm{I} / \mathrm{II}$ & 6 & R/R DLBCL & & & & & & \multirow{3}{*}{$\begin{array}{l}\text { Gastrointestinal disorders, } \\
\text { hematologic events } \\
\text { fatigue, nausea, diarrhea } \\
\text { gd } 3 \text { hematologic events }\end{array}$} & NCT02252146 \\
\hline HDAC & Mocetinostat & II & 72 & R/R DLBCL, FL & 18.9/11.5 & $2.7 / 3.8$ & $2.1 / 3.7$ & ND & ND & & Batlevi et al. \\
\hline Bcl-2 & Venetoclax & I & 106 & R/R NHL & 44 & 13 & 6 & ND & ND & & Davids et al. \\
\hline \multicolumn{12}{|l|}{ Monoclonal Antibodies } \\
\hline $\mathrm{CD} 20$ & Ofatumumab & III & 36 & FL & 84 & 16 & 1.9 & 23.7 & 30.7 & \multirow{2}{*}{$\begin{array}{c}\text { gd } 3 \text { infusion reactions } \\
\text { diarrhea, anorexia, } \\
\text { hyponatremia, fatigue }\end{array}$} & Rosenbaum et al. \\
\hline $\mathrm{CD} 20$ & Ofatumumab & II & 11 & $\mathrm{R} / \mathrm{R} \mathrm{DLBCL}$ & 18 & 0 & 2 & ND & 38 & & Galanina et al. \\
\hline CD19 (+proteasome) & $\begin{array}{l}\text { MOR-208 (+ } \\
\text { lenalidomide) }\end{array}$ & II & 81 & $\mathrm{R} / \mathrm{R} \mathrm{DLBCL}$ & 54 & 32 & 16,2 & NR & 12 & gd 3 neutropenia & Salles et al. \\
\hline $\mathrm{CD} 40$ & Dacetuzumab & II & 46 & $\mathrm{R} / \mathrm{R} \mathrm{DLBCL}$ & 9 & 4 & 1.2 & ND & ND & $\begin{array}{l}\text { thrombosis, ocular events, } \mathrm{gd} \\
3 / 4 \text { hematologic events }\end{array}$ & Sven de Vos et al. \\
\hline CD79 b (+ CD20) & $\begin{array}{l}\text { Polatuzumab } \\
\text { vedotin }(+ \\
\text { rituximab) }\end{array}$ & II & 59 & R/R DLBCL, FL & $54 / 70$ & $21 / 45$ & $5.6 / 15.3$ & $13.4 / 9.4$ & $17.4 / \mathrm{NE}$ & hematologic events, diarrhea & Morschhauser et al. \\
\hline \multicolumn{12}{|l|}{ BiTE Antibodies } \\
\hline CD19/CD3 & Blinatumomab & II & 21 & $\mathrm{R} / \mathrm{R} \mathrm{DLBCL}$ & 43 & 19 & 3.7 & 13.4 & ND & \multirow{2}{*}{$\begin{array}{c}\text { tremor, gd } 3 \text { neurologic events } \\
\text { CRS } 28.4 \% \text {, neurological events } \\
44 \%\end{array}$} & Viardot et al. \\
\hline CD20/CD3 & Mosunetuzumab & $\mathrm{I} / \mathrm{lb}$ & 218 & R/R NHL & 43.8 & 25 & ND & ND & ND & & Schuster et al. \\
\hline $\begin{array}{l}\text { Fusion Proteins } \\
\text { CD20 } \\
\text { Tumor Vaccine }\end{array}$ & DI-Leu16-IL2 & I & 9 & NHL & & & & & & & NCT00720135 \\
\hline Idiotype protein & $\underset{\mathrm{T}}{\text { Mitumprotimut }}$ & III & 174 & $\mathrm{FL}$ & 64 & 40 & ND & ND & ND & injection site reactions & Freedman et al. \\
\hline Idiotype gene & DNA vaccine & I & ND & NHL & & & & & & & ISRCTN31090206 \\
\hline APCs & $\begin{array}{l}\text { Cellular } \\
\text { vaccine }\end{array}$ & pilot & 18 & NHL & 33.3 & $16 \%$ & ND & ND & 50.5 & injection site reactions & Di Nicola et al. \\
\hline $\begin{array}{c}\text { Dendritic cells } \\
\text { Immune Check Point } \\
\text { Inhibitors }\end{array}$ & In situ vaccine & $\mathrm{I} / \mathrm{II}$ & 30 & Indolent BCL & & & & & & & NCT01976585 \\
\hline CTLA-4 (+ CD20) & $\begin{array}{l}\text { Ipilimumab (+ } \\
\text { rituximab) }\end{array}$ & I & 33 & R/R NHL & 24 & 6 & 2.6 & ND & ND & diarrhea, rash, abdominal pain & Tuscano et al. \\
\hline
\end{tabular}


Table 1. Cont.

\begin{tabular}{|c|c|c|c|c|c|c|c|c|c|c|c|}
\hline Target & Treatment & Phase & $\begin{array}{c}\mathrm{Nb} \text { of } \\
\mathrm{pts}\end{array}$ & Pathology & ORR (\%) & CR (\%) & $\begin{array}{l}\text { Median } \\
\text { PFS (mo) }\end{array}$ & $\begin{array}{l}\text { DOR } \\
\text { (mo) }\end{array}$ & $\begin{array}{l}\text { Median f-u } \\
\text { (mo) }\end{array}$ & Adverse Effects & Reference \\
\hline \multicolumn{12}{|l|}{ CAR T-Cell } \\
\hline CD19 CAR-T cells & Axicel & II & 111 & $\mathrm{R} / \mathrm{R} \mathrm{LBCL}$ & 82 & 54 & 5.8 & 8.1 & 15.4 & $\begin{array}{c}\text { CRS } 13 \% \text {, neurological events } \\
28 \%\end{array}$ & Neelapu et al. \\
\hline CD19 CAR-T cells & Tisagenlecleucel & II & 93 & R/R DLBCL & 52 & 40 & NR & ND & ND & $\begin{array}{c}\text { CRS } 22 \% \text {, neurological events } \\
12 \%\end{array}$ & Schuster et al. \\
\hline CD19 CAR-T cells (+ PD-1) & $\begin{array}{l}\text { CD19 CAR-T } \\
\text { cells }(+ \\
\text { Nivolumab) }\end{array}$ & & 11 & R/R DLBCL & 81.8 & 45.4 & 6 & 6 & 6 & $\begin{array}{c}\text { CRS } 50 \% \text {, neurological events } \\
1 \%\end{array}$ & Cao et al. \\
\hline CD19 CAR-T cells + PD-1 & Pembrolizumab & $\mathrm{I} / \mathrm{II}$ & 12 & $\begin{array}{l}\text { R/R NHL after } \\
\text { CD19 CAR-T } \\
\text { cell }\end{array}$ & & & & & & & NCT02650999 \\
\hline CD19 CAR-T cells & $\begin{array}{l}\text { CD19 CAR-T } \\
\text { cells + IL-2 }\end{array}$ & I & 60 & BCL & & & & & & & NCT00968760 \\
\hline
\end{tabular}

APCs, antigen-presenting cells; BCL, B-cell lymphoma; BTK, Bruton tyrosine kinase; CLL/SLL, chronic lymphocytic leukemia/Small lymphocytic leukemia; CR, complete response;

CRS, cytokine release syndrome; DLBCL diffuse large B-cell lymphoma; DOR, duration of response; f-u, follow-up; FL, follicular lymphoma; Gd, grade; HDAC, histone deacetylases;

MCL, mantle cell lymphoma; mo, months; Nb, number; ND, not documented; NE, not estimable; NHL, non-Hodgkin lymphoma; NR, not reached; ORR, overall response rate;

PCDLBCL, LT, primary cutaneous diffuse large B-cell lymphoma, leg type; PFS, progression free survival; PI3 K $\delta$, phosphatidylinositol 3-kinase $\delta$; PKC $\beta$, protein kinase C $\beta$; Pts, patients; $\mathrm{R} / \mathrm{R}$, refractory/relapse. 


\subsection{Small Molecule Inhibitors}

Since the discovery of the oncogenic activity of MYD88 mutations, small molecules inhibitors have been used in DLBCL. A case report described the efficacy of ibrutinib in PCDLBCL, LT [83]. Next generation BTK inhibitors such as acalabrutinib and zanubrutinib are already used in other lymphomas [86-88].

The PI3 K/AKT pathway and mTOR signaling pathway play an important role in lymphomagenesis by transducing BCR activation signals [89]. mTOR inhibition with everolimus and temsirolimus, PI3 K inhibition with parsaclisib are rescue treatments of relapsed and refractory NHL [90] By targeting the PI3 K/AKT/mTOR cascade, these treatments reduce BCR signaling. A protein kinase C inhibitor, enzastaurin, that regulates the PI3 K, MAPK and JAK/STAT pathways in vitro, seems to act synergistically with ibrutinib in DLBCL $[91,92]$.

Some Toll-Like-Receptors such as TLR7, TLR8 and TLR9 interact with MYD88. Immunomodulatory oligonucleotides (IMO) are used in immune-mediated inflammatory diseases [93,94]. IMO-8400, an antagonist of TLR7, TLR8 and TLR9 has been studied in patients with MYD88(L265 P)-positive DLBCL (NCT02252146).

Histone deacetylases (HDAC) are enzymes that interfere with immune surveillance. HDAC inhibitors can reverse immunosuppressive tumor environments. HDAC inhibitor monotherapy in B-cell lymphomas showed modest clinical benefit. The combination of HDAC inhibitor and immunotherapy could help overcome immunotherapy resistance by different mechanisms especially by modulating immune cell functions [95-97].

Although several subsets have strong Bcl-2 expression, venetoclax, a BCL2 inhibitor showed insufficient responses alone, but has been found to be a valuable ally in combination with chemo-immunotherapy [98-101].

\subsection{Monoclonal Antibodies}

Monoclonal antibodies have evolved very quickly over the last decades. Rituximab is often effective but the recurrence rate after treatment is still high in indolent and aggressive cutaneous lymphomas [6]. New generations of anti CD20 monoclonal antibodies (mABs) are designed to be more selective with less AEs and lower immunogenicity [102]. By binding to the small and the large loops of the CD20 cell surface antigen, ofatumumab improves complement-dependent cytotoxicity (CDC) and antibody-dependent cell-mediated cytotoxicity (ADCC). Ofatumumab has been used in several malignancies including DLBCL and FL [103-105].

MOR-208 is an Fc-enhanced, humanized anti-CD19 monoclonal antibody. Combination with lenalidomide showed an ORR of $58 \%$ as primary results of a phase II study in patients with relapsed or refractory DLBCL [106]. Dacetuzumab, a monoclonal anti-CD40 antibody reduced tumor bulk in a third of patients with B-cell non-Hodgkin lymphomas [107,108].

\subsection{Antibody-Drug Conjugates}

Antibody-drug conjugates (ADC) are monoclonal antibodies that bind specifically to tumorassociated target antigens and allow the delivery of highly potent cytotoxic agents.

Polatuzumab vedotin targets CD79 b using a CD79 b monoclonal antibody bound to vedotin, a toxic agent. This ADC has been studied combined with different treatments [109,110]. The CD79 protein is often expressed in PCBCL. Currently, POLARIX, a phase III trial, compares polatuzumab vedotin and R-CHOP with R-CHOP alone as initial treatment for DLBCL (NCT03274492). Targeting CD33, gemtuzumab ozogamicin is another ADC, which could be applied to PCDLBCL, LT. Expressed on most of the MDSCs, CD33 could be an interesting target in the tumor microenvironment $[69,111]$. 


\subsection{Bi-Specific T-Cell Engaging (BiTE) Antibodies}

Bi-specific T-cell engaging (BiTE) antibodies target a tumor antigen and an immune cell and lead to an antitumor immune response. Reactive T cells are often abundant in PCBCL. Binding to CD3 on T cells and CD19 on B cells, blinatumomab showed high response rates but was often associated with neurotoxicity [112].

Better tolerated, mosunetuzumab combines an anti-CD3 arm and an anti-CD20 arm. In a phase $\mathrm{I} / \mathrm{Ib}$ trial, mosunetuzumab induces durable CRs with favorable tolerability in poor prognosis NHL including patients resistant to or relapsing after CAR-T therapy. A total of 218 patients were treated, mainly DLBCL $(n=87)$. ORR rate was $64.1 \%$ in indolent subsets, $34.7 \%$ in aggressive lymphomas and $43.8 \%$ if patients had received prior CAR-T therapy [113].

\subsection{Fusion Proteins}

DI-Leu16-IL2 is a recombinant fusion protein composed of the de-immunized and humanized anti-CD20 monoclonal antibody Leu16 and the human interleukin-2 (IL2). The anti-CD20 antibody binds to tumor B-cells, which may lead to antibody-dependent cell cytotoxicity, and the IL2 moiety stimulates natural killer and T-cell immune responses. DI-Leu16-IL2 has been used in a phase I study in melanoma [114] and is being assessed in BCLs including PCBCL (NCT00720135).

\subsection{Tumor Vaccines}

Considering the indolent course of PCMZL and PCFCL and their expression of a clonal BCR, vaccines designed to target tumor idiotypes have been developed [115]. Protein vaccines were evaluated as adjuvant therapy after systemic therapy in FL with promising results [116,117]. DNA vaccines are being studied in phase I trials (ISRCTN31090206) [118,119]. Cellular vaccines with DCs may induce durable tumor regression but need further investigations [120-122]. In situ vaccines offer the possibility to develop abscopal responses when combined with radiotherapy and TLR3 agonists (NCT01976585) [123].

\subsection{Immune Checkpoint Inhibitors}

Based on the better understanding of the microenvironment and mechanisms for escaping immune surveillance in lymphomas, immune checkpoint inhibitors have been tested with variable responses depending on the type of lymphoma. Combinations of treatments are increasingly explored. In a phase I trial, ipilimumab has been used in combination with rituximab in order to improve the efficacy of rituximab by increasing T-cell activation. Ipilimumab is a humanized IgG1 monoclonal antibody against CTLA-4, a co-inhibitory receptor expressed on T cells. Efficacy was modest in the entire cohort of 33 patients with relapsed or refractory BCLs with an ORR of $24 \%$. However, the response was significantly better in follicular lymphoma patients with an ORR of 58\% [124]. Combination of rituximab and ipilimumab should be further studied in indolent lymphomas.

\subsection{Chimeric Antigen Receptor T Cells (CAR T Cells)}

Adoptive cell therapies are currently explored in lymphomas. Among them, CAR-T cells are autologous $\mathrm{T}$ cells genetically modified to express a chimeric antigen receptor (CAR). The CAR recognizes tumor-specific antigens and leads to the killing of the neoplastic cells. To date in B cell NHL, two CD19-specific CAR-T cells axicel and tisagenlecleucel are FDA-approved to treat relapsed and refractory DLBCL after at least two lines of systemic therapy [125-128]. However, serious AEs (neurological side-effects and cytokine release syndrome) and resistance to CAR T-cells are important limits. Resistance may be partly due to the ability of tumor cells to defeat immunosurveillance mechanisms but also to a restricted distribution of the CAR T-cells [129]. Combination with immune checkpoint inhibitors or cytokines are possibilities to improve the effectiveness of CAR T-cells in lymphomas (NCT02650999; NCT00968760) [130,131]. 


\section{Conclusions}

Recent advances in our knowledge of the pathophysiology of BCL have allowed the development of new targeted therapies, combination treatments and immunotherapeutic approaches. Many of them have first been used in nodal BCL and these developments could benefit patients with CBCL. The identification of predictive biomarkers of response will help select the optimal therapeutic options. In the era of personalized medicine, large-scale translational studies and prospective clinical trials are mandatory to improve the management of these rare diseases.

Author Contributions: All authors contributed to the contents of this manuscript, which was written by M.D. and A.M. and reviewed by all authors. All authors have read and agreed to the published version of the manuscript.

Funding: This research received no external funding.

Conflicts of Interest: The authors declare no conflict of interest.

\section{References}

1. Willemze, R. WHO-EORTC classification for cutaneous lymphomas. Blood 2005, 105, 3768-3785. [CrossRef] [PubMed]

2. Willemze, R.; Cerroni, L.; Kempf, W.; Berti, E.; Facchetti, F.; Swerdlow, S.H.; Jaffe, E.S. The 2018 update of the WHO-EORTC classification for primary cutaneous lymphomas. Blood 2019, 133, 1703-1714. [CrossRef] [PubMed]

3. Bradford, P.T.; Devesa, S.S.; Anderson, W.F.; Toro, J.R. Cutaneous lymphoma incidence patterns in the United States: A population-based study of 3884 cases. Blood 2009, 113, 5064-5073. [CrossRef] [PubMed]

4. Swerdlow, S.H.; Campo, E.; Pileri, S.A.; Harris, N.L.; Stein, H.; Siebert, R.; Advani, R.; Ghielmini, M.; Salles, G.A.; Zelenetz, A.D.; et al. The 2016 revision of the World Health Organization classification of lymphoid neoplasms. Blood 2016, 127, 2375-2390. [CrossRef]

5. Kim, Y.H.; Willemze, R.; Pimpinelli, N.; Whittaker, S.; Olsen, E.A.; Ranki, A.; Dummer, R.; Hoppe, R.T. ISCL and the EORTC TNM classification system for primary cutaneous lymphomas other than mycosis fungoides and Sezary syndrome: A proposal of the International Society for Cutaneous Lymphomas (ISCL) and the Cutaneous Lymphoma Task Force of the European Organization of Research and Treatment of Cancer (EORTC). Blood 2007, 110, 479-484. [CrossRef]

6. Senff, N.J.; Noordijk, E.M.; Kim, Y.H.; Bagot, M.; Berti, E.; Cerroni, L.; Dummer, R.; Duvic, M.; Hoppe, R.T.; Pimpinelli, N.; et al. European Organization for Research and Treatment of Cancer and International Society for Cutaneous Lymphoma consensus recommendations for the management of cutaneous B-cell lymphomas. Blood 2008, 112, 1600-1609. [CrossRef]

7. Amitay-Laish, I.; Tavallaee, M.; Kim, J.; Hoppe, R.T.; Million, L.; Feinmesser, M.; Fenig, E.; Wolfe, M.E.L.; Hodak, E.; Kim, Y.H. Paediatric primary cutaneous marginal zone B-cell lymphoma: Does it differ from its adult counterpart? Br. J. Dermatol. 2017, 176, 1010-1020. [CrossRef]

8. Servitje, O.; Gallardo, F.; Estrach, T.; Pujol, R.M.; Blanco, A.; Fernandez-Sevilla, A.; Petriz, L.; Peyri, J.; Romagosa, V. Primary cutaneous marginal zone B-cell lymphoma: A clinical, histopathological, immunophenotypic and molecular genetic study of 22 cases. Br. J. Dermatol. 2002, 147, 1147-1158. [CrossRef]

9. Jubert, C.; Cosnes, A.; Clerici, T.; Gaulard, P.; André, P.; Revuz, J.; Bagot, M. Sjögren's syndrome and cutaneous B cell lymphoma revealed by anetoderma. Arthritis Rheum. 1993, 36, 133-134. [CrossRef]

10. Dangien, A.; Beylot-Barry, M.; Battistella, M.; Ram-Wolff, C.; Talbot, A.; Rybojad, M.; Vergier, B.; Jachiet, M.; Bouaziz, J.-D.; Arnulf, B.; et al. Clinical presentation, therapeutic approach and outcome of primary cutaneous marginal zone B-cell lymphoma presenting as AL amyloidoma of the skin. Br. J. Dermatol. 2019, 181, 607-609. [CrossRef]

11. Kempf, W.; Zimmermann, A.; Mitteldorf, C. Cutaneous lymphomas-An update 2019. Hematol. Oncol. 2019, 37, 43-47. [CrossRef]

12. Magro, C.M.; Yang, A.; Fraga, G. Blastic marginal zone lymphoma: A Clinical and pathological study of 8 cases and review of the literature. Am. J. Dermatopathol. 2013, 35, 319-326. [CrossRef] [PubMed]

13. Swerdlow, S.H. Cutaneous marginal zone lymphomas. Semin. Diagn. Pathol. 2017, 34, 76-84. [CrossRef] [PubMed] 
14. Edinger, J.T.; Kant, J.A.; Swerdlow, S.H. Cutaneous marginal zone lymphomas have distinctive features and Include 2 subsets. Am. J. Surg. Pathol. 2010, 34, 1830-1841. [CrossRef] [PubMed]

15. Van Maldegem, F.; van Dijk, R.; Wormhoudt, T.A.M.; Kluin, P.M.; Willemze, R.; Cerroni, L.; van Noesel, C.J.M.; Bende, R.J. The majority of cutaneous marginal zone B-cell lymphomas expresses class-switched immunoglobulins and develops in a T-helper type 2 inflammatory environment. Blood 2008, 112, 3355-3361. [CrossRef] [PubMed]

16. Sun, J.R.; Nong, L.; Liu, X.Q.; Tu, P.; Wang, Y. Frequent immunoglobulin G4 expression in a common variant of primary cutaneous marginal zone B-cell lymphoma. Australas. J. Dermatol. 2018, 59, 141-145. [CrossRef]

17. Machan, S.; Medina, C.; Rodríguez-Pinilla, S.M.; Suárez-Peñaranda, J.M.; Castro, Y.; Molés, P.; Requena, C.; Saus, C.; Requena, L.; Santonja, C. Primary cutaneous marginal IgG4 Lymphoma and rosai-dorfman's disease coexisting in several lesions of the same patient. Am. J. Dermatopathol. 2015, 37, 413-418. [CrossRef]

18. Maurus, K.; Appenzeller, S.; Roth, S.; Kuper, J.; Rost, S.; Meierjohann, S.; Arampatzi, P.; Goebeler, M.; Rosenwald, A.; Geissinger, E.; et al. Panel Sequencing shows recurrent genetic FAS Alterations in Primary cutaneous marginal zone lymphoma. J. Investig. Dermatol. 2018, 138, 1573-1581. [CrossRef]

19. Streubel, B.; Simonitsch-Klupp, I.; Müllauer, L.; Lamprecht, A.; Huber, D.; Siebert, R.; Stolte, M.; Trautinger, F.; Lukas, J.; Püspök, A.; et al. Variable frequencies of MALT lymphoma-associated genetic aberrations in MALT lymphomas of different sites. Leukemia 2004, 18, 1722-1726. [CrossRef]

20. Cerroni, L.; Zöchling, N.; Pütz, B.; Kerl, H. Infection by Borrelia burgdorferi and cutaneous B-cell lymphoma. J. Cutan. Pathol. 1997, 24, 457-461. [CrossRef] [PubMed]

21. Mandekou-Lefaki, I.; Delli, F.; Kountouras, I.; Athanasiou, E.; Mattheou-Vakali, G. Primary cutaneous MALT-type lymphoma and Helicobacter pylori: A possible relationship. J. Eur. Acad. Dermatol. Venereol. 2006, 20, 606-608. [CrossRef]

22. Hoefnagel, J.J.; Dijkman, R.; Basso, K.; Jansen, P.M.; Hallermann, C.; Willemze, R.; Tensen, C.P.; Vermeer, M.H. Distinct types of primary cutaneous large B-cell lymphoma identified by gene expression profiling. Blood 2005, 105, 3671-3678. [CrossRef] [PubMed]

23. May, S.A.; Netto, G.; Domiati-Saad, R.; Kasper, C. Cutaneous lymphoid hyperplasia and marginal zone B-cell lymphoma following vaccination. J. Am. Acad. Dermatol. 2005, 53, 511-515. [CrossRef]

24. Guitart, J.; Deonizio, J.; Bloom, T.; Martinez-Escala, M.E.; Kuzel, T.M.; Gerami, P.; Kwasny, M.; Rosen, S.T. High incidence of gastrointestinal tract disorders and autoimmunity in primary cutaneous marginal zone B-Cell Lymphomas. JAMA Dermatol. 2014, 150, 412. [CrossRef] [PubMed]

25. Senff, N.J.; Hoefnagel, J.J.; Jansen, P.M.; Vermeer, M.H.; van Baarlen, J.; Blokx, W.A.; Canninga-van Dijk, M.R.; Geerts, M.-L.; Hebeda, K.M.; Kluin, P.M.; et al. Reclassification of 300 primary cutaneous B-Cell Lymphomas according to the new WHO-EORTC classification for cutaneous lymphomas: Comparison with previous classifications and identification of prognostic markers. J. Clin. Oncol. 2007, 25, 1581-1587. [CrossRef] [PubMed]

26. De Masson, A.; Bouaziz, J.-D.; Ram-Wolff, C.; Brice, P.; Moulonguet, I.; Vignon-Pennamen, M.-D.; Herms, F.; Verneuil, L.; Rivet, J.; Bagot, M.; et al. Alopecic patches of the scalp: A variant of primary cutaneous follicle centre B-cell lymphoma reported in a series of 14 cases. J. Eur. Acad. Dermatol. Venereol. JEADV 2019, 33, e209-e211. [CrossRef] [PubMed]

27. Aldarweesh, F.A.; Treaba, D.O. Primary cutaneous follicle centre lymphoma with hodgkin and reed-sternberg like cells: A case report and review of the literature. Case Rep. Hematol. 2017, 2017, 1-5. [CrossRef] [PubMed]

28. Cassisa, A.; Colpani, F.; Rinaldi, R.; Cima, L. Primary cutaneous follicle center lymphoma clear cell variant: Expanding the Spectrum of cutaneous clear cell neoplasms. Am. J. Dermatopathol. 2018, 40, 849-853. [CrossRef]

29. Oschlies, I.; Kohler, C.W.; Szczepanowski, M.; Koch, K.; Gontarewicz, A.; Metze, D.; Hillen, U.; Richter, J.; Spang, R.; Klapper, W. Spindle-Cell variants of primary cutaneous follicle center B-Cell lymphomas are germinal center B-Cell lymphomas by gene expression profiling using a formalin-fixed paraffin-embedded specimen. J. Investig. Dermatol. 2017, 137, 2450-2453. [CrossRef]

30. Smith, B.D.; Smith, G.L.; Cooper, D.L.; Wilson, L.D. The cutaneous B-cell lymphoma prognostic index: A novel prognostic index derived from a population-based registry. J. Clin. Oncol. 2005, 23, 3390-3395. [CrossRef] 
31. Pham-Ledard, A.; Cowppli-Bony, A.; Doussau, A.; Prochazkova-Carlotti, M.; Laharanne, E.; Jouary, T.; Belaud-Rotureau, M.-A.; Vergier, B.; Merlio, J.-P.; Beylot-Barry, M. Diagnostic and prognostic value of BCL2 Rearrangement in 53 patients with follicular lymphoma presenting as primary skin lesions. Am. J. Clin. Pathol. 2015, 143, 362-373. [CrossRef] [PubMed]

32. Guinard, E.; Alenezi, F.; Lamant, L.; Szablewski, V.; Laurent, C.; Paul, C.; Meyer, N.; Dereure, O. Staging of Primary cutaneous follicle centre B-cell Lymphoma: Bone Marrow Biopsy, CD10, BCL2 and t (14;18) Are not relevant prognostic factors. Eur. J. Dermatol. 2019, 1. [CrossRef]

33. Goodlad, J.R.; Davidson, M.M.; Hollowood, K.; Ling, C.; MacKenzie, C.; Christie, I.; Batstone, P.J.; Ho-Yen, D.O. Primary cutaneous B-Cell lymphoma and borrelia burgdorferi infection in patients from the highlands of scotland. Am. J. Surg. Pathol. 2000, 24, 1279-1285. [CrossRef] [PubMed]

34. Wood, G.S.; Kamath, N.V.; Guitart, J.; Heald, P.; Kohler, S.; Smoller, B.R.; Cerroni, L. Absence of Borrelia burgdorferi DNA in cutaneous B-cell lymphomas from the United States. J. Cutan. Pathol. 2001, 28, 502-507. [CrossRef] [PubMed]

35. NCCN. Available online: https://www.nccn.org/professionals/physician_gls/default.aspx\#pcbcl (accessed on 6 January 2020).

36. Jonak, C.; Porkert, S.; Oerlemans, S.; Papadavid, E.; Molloy, K.; Lehner-Baumgartner, E.; Cozzio, A.; Efficace, F.; Scarisbrick, J. Health-related quality of life in cutaneous lymphomas: Past, present and future. Acta Derm. Venereol. 2019, 99, 640-646. [CrossRef] [PubMed]

37. Gauci, M.-L.; Quero, L.; Ram-Wolff, C.; Guillerm, S.; M’Barek, B.; Lebbé, C.; Bagot, M.; Hennequin, C. Outcomes of radiation therapy of indolent cutaneous B-cell lymphomas and literature review. J. Eur. Acad. Dermatol. Venereol. 2018, 32, 1668-1673. [CrossRef]

38. Goyal, A.; Carter, J.B.; Pashtan, I.; Gallotto, S.; Wang, I.; Isom, S.; Ng, A.; Winkfield, K.M. Very low-dose versus standard dose radiation therapy for indolent primary cutaneous B-cell lymphomas: A retrospective study. J. Am. Acad. Dermatol. 2018, 78, 408-410. [CrossRef]

39. Oertel, M.; Elsayad, K.; Weishaupt, C.; Steinbrink, K.; Eich, H.T. De-escalated radiotherapy for indolent primary cutaneous B-cell lymphoma. Strahlentherapie Und Onkologie 2020, 196, 126-131. [CrossRef]

40. Willemze, R.; Hodak, E.; Zinzani, P.L.; Specht, L.; Ladetto, M. Primary cutaneous lymphomas: ESMO Clinical Practice Guidelines for diagnosis, treatment and follow-up. Ann. Oncol. 2018, 29, iv30-iv40. [CrossRef]

41. Parbhakar, S.; Cin, A.D. Primary cutaneous B-cell lymphoma: Role of surgery. Can. J. Plast. Surg. 2011, 19, 12-14. [CrossRef]

42. Fernández-Guarino, M.; Ortiz-Romero, P.L.; Fernández-Misa, R.; Montalbán, C. Rituximab in the treatment of primary cutaneous B-cell lymphoma: A review. Actas Dermosifiliogr. 2014, 105, 438-445. [CrossRef]

43. Eberle, F.C.; Holstein, J.; Scheu, A.; Fend, F.; Yazdi, A.S. Intralesional anti-CD20 antibody for low-grade primary cutaneous B-cell lymphoma: Adverse reactions correlate with favorable clinical outcome: Intralesional anti-CD20 in primary cutaneous B-cell lymphoma. JDDG J. Ger. Soc. Dermatol. 2017, 15, 319-323. [CrossRef] [PubMed]

44. Kerl, K.; Prins, C.; Saurat, J.H.; French, L.E. Intralesional and intravenous treatment of cutaneous B-cell lymphomas with the monoclonal anti-CD20 antibody rituximab: Report and follow-up of eight cases. Br. J. Dermatol. 2006, 155, 1197-1200. [CrossRef] [PubMed]

45. Peñate, Y.; Hernández-Machín, B.; Pérez-Méndez, L.I.; Santiago, F.; Rosales, B.; Servitje, O.; Estrach, T.; Fernández-Guarino, M.; Calzado, L.; Acebo, E.; et al. Intralesional rituximab in the treatment of indolent primary cutaneous B-cell lymphomas: An epidemiological observational multicentre study. The Spanish Working Group on Cutaneous Lymphoma. Br. J. Dermatol. 2012, 167, 174-179. [CrossRef] [PubMed]

46. Vandersee, S.; Terhorst, D.; Humme, D.; Beyer, M. Treatment of indolent primary cutaneous B-cell lymphomas with subcutaneous interferon-alfa. J. Am. Acad. Dermatol. 2014, 70, 709-715. [CrossRef] [PubMed]

47. Cozzio, A.; Kempf, W.; Schmid-Meyer, R.; Gilliet, M.; Michaelis, S.; Schärer, L.; Burg, G.; Dummer, R. Intra-lesional low-dose interferon alpha2a therapy for primary cutaneous marginal zone B-cell lymphoma. Leuk. Lymphoma 2006, 47, 865-869. [CrossRef]

48. Maza, S.; Gellrich, S.; Assaf, C.; Beyer, M.; Spilker, L.; Orawa, H.; Munz, D.L.; Sterry, W.; Steinhoff, M. Yttrium-90 ibritumomab tiuxetan radioimmunotherapy in primary cutaneous B-cell lymphomas: First results of a prospective, monocentre study. Leuk. Lymphoma 2008, 49, 1702-1709. [CrossRef] 
49. Di, M.; Ollila, T.A.; Olszewski, A.J. Exposure to ibritumomab tiuxetan and incidence of treatment-related myeloid neoplasms among older patients with B-cell lymphoma: A population-based study. Leukemia 2020. [CrossRef]

50. Leonard, J.P.; Trneny, M.; Izutsu, K.; Fowler, N.H.; Hong, X.; Zhu, J.; Zhang, H.; Offner, F.; Scheliga, A.; Nowakowski, G.S.; et al. AUGMENT: A phase III study of lenalidomide plus rituximab versus placebo plus rituximab in relapsed or refractory indolent lymphoma. J. Clin. Oncol. 2019, 37, 1188-1199. [CrossRef]

51. Dummer, R.; Eichmüller, S.; Gellrich, S.; Assaf, C.; Dreno, B.; Schiller, M.; Dereure, O.; Baudard, M.; Bagot, M.; Khammari, A.; et al. Phase II clinical trial of intratumoral application of TG1042 (Adenovirus-interferon- $\gamma$ ) in patients with advanced cutaneous T-cell lymphomas and multilesional cutaneous B-cell lymphomas. Mol. Ther. 2010, 18, 1244-1247. [CrossRef]

52. Dummer, R.; Hassel, J.C.; Fellenberg, F.; Eichmüller, S.; Maier, T.; Slos, P.; Acres, B.; Bleuzen, P.; Bataille, V.; Squiban, P.; et al. Adenovirus-mediated intralesional interferon- $\gamma$ gene transfer induces tumor regressions in cutaneous lymphomas. Blood 2004, 104, 1631-1638. [CrossRef] [PubMed]

53. Dreno, B.; Urosevic-Maiwald, M.; Kim, Y.; Guitart, J.; Duvic, M.; Dereure, O.; Khammari, A.; Knol, A.-C.; Derbij, A.; Lusky, M.; et al. TG1042 (Adenovirus-interferon- $\gamma$ ) in primary cutaneous B-cell lymphomas: A Phase II clinical trial. PLoS ONE 2014, 9, e83670. [CrossRef] [PubMed]

54. Hwang, S.; Johnson, A.; Fabbro, S.; Hastings, J.; Haverkos, B.; Chung, C.; Porcu, P.; William, B. Topical imiquimod monotherapy for indolent primary cutaneous B-cell lymphomas: A single-institution experience. Br. J. Dermatol. 2020. [CrossRef] [PubMed]

55. Vermeer, M.H.; Geelen, F.A.; van Haselen, C.W.; van Voorst Vader, P.C.; Geerts, M.L.; van Vloten, W.A.; Willemze, R. Primary cutaneous large B-cell lymphomas of the legs. A distinct type of cutaneous B-cell lymphoma with an intermediate prognosis. Arch. Dermatol. 1996, 132, 1304-1308. [CrossRef]

56. Grange, F.; Joly, P.; Barbe, C.; Bagot, M.; Dalle, S.; Ingen-Housz-Oro, S.; Maubec, E.; D’Incan, M.; Ram-Wolff, C.; Dalac, S.; et al. Improvement of Survival in Patients With Primary Cutaneous Diffuse Large B-Cell Lymphoma, Leg Type, in France. JAMA Dermatol. 2014, 150, 535. [CrossRef]

57. Paulli, M.; Viglio, A.; Vivenza, D.; Capello, D.; Rossi, D.; Riboni, R.; Lucioni, M.; Incardona, P.; Boveri, E.; Bellosta, M.; et al. Primary cutaneous large B-cell lymphoma of the leg: Histogenetic analysis of a controversial clinicopathologic entity. Hum. Pathol. 2002, 33, 937-943. [CrossRef]

58. Brogan, B.L.; Zic, J.A.; Kinney, M.C.; Hu, J.Y.; Hamilton, K.S.; Greer, J.P. Large B-cell lymphoma of the leg: Clinical and pathologic characteristics in a north american series. J. Am. Acad. Dermatol. 2003, 49, 223-228. [CrossRef]

59. Menguy, S.; Frison, E.; Prochazkova-Carlotti, M.; Dalle, S.; Dereure, O.; Boulinguez, S.; Dalac, S.; Machet, L.; Ram-Wolff, C.; Verneuil, L.; et al. Double-hit or dual expression of MYC and BCL2 in primary cutaneous large B-cell lymphomas. Mod. Pathol. 2018, 31, 1332-1342. [CrossRef]

60. Koens, L.; Vermeer, M.H.; Willemze, R.; Jansen, P.M. IgM Expression on paraffin sections distinguishes primary cutaneous large B-cell lymphoma, leg type from primary cutaneous follicle center lymphoma. Am. J. Surg. Pathol. 2010, 34, 1043-1048. [CrossRef]

61. Mareschal, S.; Pham-Ledard, A.; Viailly, P.J.; Dubois, S.; Bertrand, P.; Maingonnat, C.; Fontanilles, M.; Bohers, E.; Ruminy, P.; Tournier, I.; et al. Identification of somatic mutations in primary cutaneous diffuse large B-Cell Lymphoma, leg type by massive parallel sequencing. J. Investig. Dermatol. 2017, 137, 1984-1994. [CrossRef]

62. Grange, F.; Beylot-Barry, M.; Courville, P.; Maubec, E.; Bagot, M.; Vergier, B.; Souteyrand, P.; Machet, L.; Dalac, S.; Esteve, E.; et al. Primary cutaneous diffuse large B-Cell Lymphoma, leg type. Arch. Dermatol. 2007, 143, 7. [CrossRef] [PubMed]

63. Pham-Ledard, A.; Cappellen, D.; Martinez, F.; Vergier, B.; Beylot-Barry, M.; Merlio, J.-P. MYD88 Somatic Mutation is a genetic feature of primary cutaneous diffuse large B-Cell Lymphoma, leg type. J. Investig. Dermatol. 2012, 132, 2118-2120. [CrossRef] [PubMed]

64. Pham-Ledard, A.; Prochazkova-Carlotti, M.; Andrique, L.; Cappellen, D.; Vergier, B.; Martinez, F.; Grange, F.; Petrella, T.; Beylot-Barry, M.; Merlio, J.-P. Multiple genetic alterations in primary cutaneous large B-cell lymphoma, leg type support a common lymphomagenesis with activated B-cell-like diffuse large B-cell lymphoma. Mod. Pathol. 2014, 27, 402-411. [CrossRef] [PubMed] 
65. Dijkman, R.; Tensen, C.P.; Jordanova, E.S.; Knijnenburg, J.; Hoefnagel, J.J.; Mulder, A.A.; Rosenberg, C.; Raap, A.K.; Willemze, R.; Szuhai, K.; et al. Array-Based comparative genomic hybridization analysis reveals recurrent chromosomal alterations and prognostic parameters in primary cutaneous large B-Cell Lymphoma. J. Clin. Oncol. 2006, 24, 296-305. [CrossRef]

66. Senff, N.J.; Zoutman, W.H.; Vermeer, M.H.; Assaf, C.; Berti, E.; Cerroni, L.; Espinet, B.; de Misa Cabrera, R.F.; Geerts, M.-L.; Kempf, W.; et al. Fine-Mapping chromosomal loss at 9p21: Correlation with prognosis in primary cutaneous diffuse large B-Cell Lymphoma, leg type. J. Investig. Dermatol. 2009, 129, 1149-1155. [CrossRef]

67. Schrader, A.M.R.; Jansen, P.M.; Vermeer, M.H.; Kleiverda, J.K.; Vermaat, J.S.P.; Willemze, R. High incidence and clinical significance of MYC Rearrangements in primary cutaneous diffuse large B-Cell Lymphoma, leg type. Am. J. Surg. Pathol. 2018, 42, 1488-1494. [CrossRef]

68. Zhou, X.A.; Louissaint, A.; Wenzel, A.; Yang, J.; Martinez-Escala, M.E.; Moy, A.P.; Morgan, E.A.; Paxton, C.N.; Hong, B.; Andersen, E.F.; et al. Genomic Analyses identify recurrent alterations in immune evasion genes in diffuse large B-Cell Lymphoma, leg type. J. Investig. Dermatol. 2018, 138, 2365-2376. [CrossRef]

69. Mitteldorf, C.; Berisha, A.; Pfaltz, M.C.; Broekaert, S.M.C.; Schön, M.P.; Kerl, K.; Kempf, W. Tumor microenvironment and checkpoint molecules in primary cutaneous diffuse large B-Cell LymphomaNew therapeutic targets. Am. J. Surg. Pathol. 2017, 41, 998-1004. [CrossRef]

70. Menguy, S.; Prochazkova-Carlotti, M.; Beylot-Barry, M.; Saltel, F.; Vergier, B.; Merlio, J.-P.; Pham-Ledard, A. PD-L1 and PD-L2 are differentially expressed by macrophages or tumor cells in primary cutaneous diffuse large B-Cell Lymphoma, leg type. Am. J. Surg. Pathol. 2018, 42, 326-334. [CrossRef]

71. Felcht, M.; Heck, M.; Weiss, C.; Becker, J.C.; Dippel, E.; Müller, C.S.L.; Nashan, D.; Sachse, M.M.; Nicolay, J.P.; Booken, N.; et al. Expression of the T-cell regulatory marker FOXP3 in primary cutaneous large B-cell lymphoma tumour cells. Br. J. Dermatol. 2012, 167, 348-358. [CrossRef]

72. Hamilton, S.N.; Wai, E.S.; Tan, K.; Alexander, C.; Gascoyne, R.D.; Connors, J.M. Treatment and outcomes in patients with primary cutaneous B-Cell Lymphoma: The BC Cancer agency experience. Int. J. Radiat. Oncol. 2013, 87, 719-725. [CrossRef] [PubMed]

73. Grange, F.; Maubec, E.; Bagot, M.; Beylot-Barry, M.; Joly, P.; Dalle, S.; Delaporte, E.; Dereure, O.; Bachelez, H.; Vergier, B.; et al. Treatment of cutaneous B-Cell Lymphoma, leg type, with age-adapted combinations of chemotherapies and rituximab. Arch. Dermatol. 2009, 145. [CrossRef] [PubMed]

74. Pulini, S.; Rupoli, S.; Goteri, G.; Pimpinelli, N.; Alterini, R.; Bettacchi, A.; Mulattieri, S.; Picardi, P.; Tassetti, A.; Scortechini, A.R.; et al. Efficacy and safety of pegylated liposomal doxorubicin in primary cutaneous B-cell lymphomas and comparison with the commonly used therapies. Eur. J. Haematol. 2009, 82, 184-193. [CrossRef] [PubMed]

75. Fabbri, A.; Cencini, E.; Alterini, R.; Rubegni, P.; Rigacci, L.; Delfino, C.; Puccini, B.; Fimiani, M.; Bosi, A.; Bocchia, M.; et al. Rituximab plus liposomal pegylated doxorubicin in the treatment of primary cutaneous B-cell lymphomas. Eur. J. Haematol. 2014, 93, 129-136. [CrossRef]

76. Hong, J.Y.; Yoon, D.H.; Suh, C.; Kim, W.S.; Kim, S.J.; Jo, J.-C.; Kim, J.S.; Lee, W.-S.; Oh, S.Y.; Park, Y.; et al. Bendamustine plus rituximab for relapsed or refractory diffuse large B cell lymphoma: A multicenter retrospective analysis. Ann. Hematol. 2018, 97, 1437-1443. [CrossRef]

77. Zeremski, V.; Jentsch-Ullrich, K.; Kahl, C.; Mohren, M.; Eberhardt, J.; Fischer, T.; Schalk, E. Is bendamustinerituximab a reasonable treatment in selected older patients with diffuse large B cell lymphoma? Results from a multicentre, retrospective study. Ann. Hematol. 2019, 98, 2729-2737. [CrossRef] [PubMed]

78. Wollina, U.; Schmidt, N.; Schönlebe, J.; Vojvodic, A.; Hansel, G.; Koch, A.; Lotti, T. Large B-Cell Lymphoma of the Leg-Unfavourable Course with Rituximab/Bendamustin. Open Access Maced. J. Med. Sci. $2019,7$. [CrossRef]

79. Kobold, S.; Killic, N.; Lütkens, T.; Bokemeyer, C.; Fiedler, W. Isolated limb perfusion with melphalan for the treatment of intractable primary cutaneous diffuse large B-Cell Lymphoma leg type. Acta Haematol. 2010, 123, 179-181. [CrossRef]

80. Ducharme, O.; Beylot-Barry, M.; Pham-Ledard, A.; Bohers, E.; Viailly, P.-J.; Bandres, T.; Faur, N.; Frison, E.; Vergier, B.; Jardin, F.; et al. Mutations of the B-Cell receptor pathway confer chemoresistance in primary cutaneous diffuse large B-Cell Lymphoma leg type. J. Investig. Dermatol. 2019, 139, 2334-2342.e8. [CrossRef] 
81. Wilson, W.H.; Young, R.M.; Schmitz, R.; Yang, Y.; Pittaluga, S.; Wright, G.; Lih, C.-J.; Williams, P.M.; Shaffer, A.L.; Gerecitano, J.; et al. Targeting B cell receptor signaling with ibrutinib in diffuse large B cell lymphoma. Nat. Med. 2015, 21, 922-926. [CrossRef]

82. Kuo, H.-P.; Ezell, S.A.; Hsieh, S.; Schweighofer, K.J.; Cheung, L.W.; Wu, S.; Apatira, M.; Sirisawad, M.; Eckert, K.; Liang, Y.; et al. The role of PIM1 in the ibrutinib-resistant ABC subtype of diffuse large B-cell lymphoma. Am. J. Cancer Res. 2016, 6, 2489-2501. [CrossRef] [PubMed]

83. Gupta, E.; Accurso, J.; Sluzevich, J.; Menke, D.M.; Tun, H.W. Excellent outcome of immunomodulation or bruton's tyrosine kinase inhibition in highly refractory primary cutaneous diffuse large B-Cell Lymphoma, Leg type. Rare Tumors 2015, 7, 164-166. [CrossRef] [PubMed]

84. Beylot-Barry, M.; Mermin, D.; Maillard, A.; Bouabdallah, R.; Bonnet, N.; Duval-Modeste, A.-B.; Mortier, L.; Ingen-Housz-Oro, S.; Ram-Wolff, C.; Barete, S.; et al. A Single-Arm Phase II trial of lenalidomide in relapsing or refractory primary cutaneous large B-Cell Lymphoma, leg type. J. Investig. Dermatol. 2018, 138, 1982-1989. [CrossRef] [PubMed]

85. Di Raimondo, C.; Abdulla, F.R.; Zain, J.; Querfeld, C.; Rosen, S.T. Rituximab, lenalidomide and pembrolizumab in refractory primary cutaneous diffuse large B-cell lymphoma, leg type. Br. J. Haematol. 2019, 187. [CrossRef] [PubMed]

86. Wang, M.; Rule, S.; Zinzani, P.L.; Goy, A.; Casasnovas, O.; Smith, S.D.; Damaj, G.; Doorduijn, J.; Lamy, T.; Morschhauser, F.; et al. Acalabrutinib in relapsed or refractory mantle cell lymphoma (ACE-LY-004): A single-arm, multicentre, phase 2 trial. Lancet 2018, 391, 659-667. [CrossRef]

87. Li, C.J.; Jiang, C.; Liu, Y.; Bell, T.; Ma, W.; Ye, Y.; Huang, S.; Guo, H.; Zhang, H.; Wang, L.; et al. Pleiotropic Action of Novel Bruton's Tyrosine kinase inhibitor BGB-3111 in mantle cell lymphoma. Mol. Cancer Ther. 2019, 18, 267-277. [CrossRef] [PubMed]

88. Tam, C.S.; Trotman, J.; Opat, S.; Burger, J.A.; Cull, G.; Gottlieb, D.; Harrup, R.; Johnston, P.B.; Marlton, P.; Munoz, J.; et al. Phase 1 study of the selective BTK inhibitor zanubrutinib in B-cell malignancies and safety and efficacy evaluation in CLL. Blood 2019, 134, 851-859. [CrossRef]

89. De Groen, R.A.L.; Schrader, A.M.R.; Kersten, M.J.; Pals, S.T.; Vermaat, J.S.P. MYD88 in the driver's seat of B-cell lymphomagenesis: From molecular mechanisms to clinical implications. Haematologica 2019, 104, 2337-2348. [CrossRef]

90. Forero-Torres, A.; Ramchandren, R.; Yacoub, A.; Wertheim, M.S.; Edenfield, W.J.; Caimi, P.; Gutierrez, M.; Akard, L.; Escobar, C.; Call, J.; et al. Parsaclisib, a potent and highly selective PI3K $\delta$ inhibitor, in patients with relapsed or refractory B-cell malignancies. Blood 2019, 133, 1742-1752. [CrossRef]

91. He, Y.; Li, J.; Ding, N.; Wang, X.; Deng, L.; Xie, Y.; Ying, Z.; Liu, W.; Ping, L.; Zhang, C.; et al. Combination of Enzastaurin and Ibrutinib synergistically induces anti-tumor effects in diffuse large B cell lymphoma. J. Exp. Clin. Cancer Res. 2019, 38, 86. [CrossRef]

92. Crump, M.; Leppä, S.; Fayad, L.; Lee, J.J.; Di Rocco, A.; Ogura, M.; Hagberg, H.; Schnell, F.; Rifkin, R.; Mackensen, A.; et al. Randomized, double-blind, Phase III trial of enzastaurin versus placebo in patients achieving remission after first-line therapy for high-risk diffuse large B-Cell Lymphoma. J. Clin. Oncol. 2016, 34, 2484-2492. [CrossRef] [PubMed]

93. Sun, S.; Rao, N.L.; Venable, J.; Thurmond, R.; Karlsson, L. TLR7/9 antagonists as therapeutics for immune-mediated inflammatory disorders. Inflamm. Allergy Drug Targets 2007, 6, 223-235. [CrossRef] [PubMed]

94. Balak, D.M.W.; van Doorn, M.B.A.; Arbeit, R.D.; Rijneveld, R.; Klaassen, E.; Sullivan, T.; Brevard, J.; Thio, H.B.; Prens, E.P.; Burggraaf, J.; et al. IMO-8400, a toll-like receptor 7, 8, and 9 antagonist, demonstrates clinical activity in a phase $2 \mathrm{a}$, randomized, placebo-controlled trial in patients with moderate-to-severe plaque psoriasis. Clin. Immunol. 2017, 174, 63-72. [CrossRef]

95. Wang, X.; Waschke, B.C.; Woolaver, R.A.; Chen, S.M.Y.; Chen, Z.; Wang, J.H. HDAC inhibitors overcome immunotherapy resistance in B-cell lymphoma. Protein Cell 2020. [CrossRef] [PubMed]

96. Crisci, S.; Di Francia, R.; Mele, S.; Vitale, P.; Ronga, G.; De Filippi, R.; Berretta, M.; Rossi, P.; Pinto, A. Overview of targeted drugs for mature B-Cell non-hodgkin lymphomas. Front. Oncol. 2019, 9, 443. [CrossRef]

97. Batlevi, C.L.; Crump, M.; Andreadis, C.; Rizzieri, D.; Assouline, S.E.; Fox, S.; van der Jagt, R.H.C.; Copeland, A.; Potvin, D.; Chao, R.; et al. A phase 2 study of mocetinostat, a histone deacetylase inhibitor, in relapsed or refractory lymphoma. Br. J. Haematol. 2017, 178, 434-441. [CrossRef]

98. Cang, S.; Iragavarapu, C.; Savooji, J.; Song, Y.; Liu, D. ABT-199 (venetoclax) and BCL-2 inhibitors in clinical development. J. Hematol. Oncol. 2015, 8, 129. [CrossRef] 
99. Kater, A.P.; Seymour, J.F.; Hillmen, P.; Eichhorst, B.; Langerak, A.W.; Owen, C.; Verdugo, M.; Wu, J.; Punnoose, E.A.; Jiang, Y.; et al. Fixed duration of venetoclax-rituximab in relapsed/refractory chronic lymphocytic leukemia eradicates minimal residual disease and prolongs survival: Post-Treatment follow-up of the MURANO Phase III study. J. Clin. Oncol. 2019, 37, 269-277. [CrossRef]

100. Khan, N.; Kahl, B. Targeting BCL-2 in hematologic malignancies. Target Oncol. 2018, 13, 257-267. [CrossRef]

101. Davids, M.S.; Roberts, A.W.; Seymour, J.F.; Pagel, J.M.; Kahl, B.S.; Wierda, W.G.; Puvvada, S.; Kipps, T.J.; Anderson, M.A.; Salem, A.H.; et al. Phase I First-in-human study of venetoclax in patients with relapsed or refractory non-hodgkin lymphoma. J. Clin. Oncol. 2017, 35, 826-833. [CrossRef]

102. Tadiotto Cicogna, G.; Ferranti, M.; Lazzarotto, A.; Alaibac, M. Biological Approaches to Aggressive Cutaneous B-Cell Lymphomas. Front. Oncol. 2019, 9, 1238. [CrossRef]

103. Gupta, I.V.; Jewell, R.C. Ofatumumab, the first human anti-CD20 monoclonal antibody for the treatment of B cell hematologic malignancies. Ann. N. Y. Acad. Sci. 2012, 1263, 43-56. [CrossRef]

104. Rosenbaum, C.A.; Jung, S.; Pitcher, B.; Bartlett, N.L.; Smith, S.M.; Hsi, E.; Wagner-Johnston, N.; Thomas, S.P.; Leonard, J.P.; Cheson, B.D. Phase 2 multicentre study of single-agent ofatumumab in previously untreated follicular lymphoma: CALGB 50901 (Alliance). Br. J. Haematol. 2019, 185, 53-64. [CrossRef]

105. Galanina, N.; Jasielec, J.; Peace, D.; Smith, S.M.; Nabhan, C. Ofatumumab monotherapy in relapsed/refractory diffuse large B-cell non-Hodgkin lymphoma. Leuk. Lymphoma 2017, 58, 752-753. [CrossRef] [PubMed]

106. Salles, G.; Duell, J.; Barca, E.G.; Jurczak, W.; Liberati, A.M.; Nagy, Z.; Obr, A.; Gaidano, G.; Andre, M.; Kalakonda, N.; et al. Primary analysis results of the single-arm phase Ii Study of Mor208 Plus Lenalidomide in patients with relapsed or refractory diffuse large B-Cell Lymphoma (l-Mind). Hematol. Oncol. 2019, 37, 173-174. [CrossRef]

107. Advani, R.; Forero-Torres, A.; Furman, R.R.; Rosenblatt, J.D.; Younes, A.; Ren, H.; Harrop, K.; Whiting, N.; Drachman, J.G. Phase I study of the humanized anti-CD40 monoclonal antibody dacetuzumab in refractory or recurrent non-Hodgkin's lymphoma. J. Clin. Oncol. Am. Soc. Clin. Oncol. J. 2009, 27, 4371-4377. [CrossRef] [PubMed]

108. De Vos, S.; Forero-Torres, A.; Ansell, S.M.; Kahl, B.; Cheson, B.D.; Bartlett, N.L.; Furman, R.R.; Winter, J.N.; Kaplan, H.; Timmerman, J.; et al. A phase II study of dacetuzumab (SGN-40) in patients with relapsed diffuse large B-cell lymphoma (DLBCL) and correlative analyses of patient-specific factors. J. Hematol. Oncol. 2014, 7, 44. [CrossRef]

109. Choi, Y.; Diefenbach, C.S. Polatuzumab Vedotin: A New target for B Cell malignancies. Curr. Hematol. Malig. Rep. 2020. [CrossRef]

110. Morschhauser, F.; Flinn, I.W.; Advani, R.; Sehn, L.H.; Diefenbach, C.; Kolibaba, K.; Press, O.W.; Salles, G.; Tilly, H.; Chen, A.I.; et al. Polatuzumab vedotin or pinatuzumab vedotin plus rituximab in patients with relapsed or refractory non-Hodgkin lymphoma: Final results from a phase 2 randomised study (ROMULUS). Lancet Haematol. 2019, 6, e254-e265. [CrossRef]

111. Jen, E.Y.; Ko, C.-W.; Lee, J.E.; Del Valle, P.L.; Aydanian, A.; Jewell, C.; Norsworthy, K.J.; Przepiorka, D.; Nie, L.; Liu, J.; et al. FDA approval: Gemtuzumab ozogamicin for the treatment of adults with newly diagnosed CD33-Positive acute myeloid leukemia. Clin. Cancer Res. 2018, 24, 3242-3246. [CrossRef]

112. Viardot, A.; Goebeler, M.-E.; Hess, G.; Neumann, S.; Pfreundschuh, M.; Adrian, N.; Zettl, F.; Libicher, M.; Sayehli, C.; Stieglmaier, J.; et al. Phase 2 study of the bispecific T-cell engager (BiTE) antibody blinatumomab in relapsed/refractory diffuse large B-cell lymphoma. Blood 2016, 127, 1410-1416. [CrossRef]

113. Schuster, S.J.; Bartlett, N.L.; Assouline, S.; Yoon, S.-S.; Bosch, F.; Sehn, L.H.; Cheah, C.Y.; Shadman, M.; Gregory, G.P.; Ku, M.; et al. Mosunetuzumab induces complete remissions in poor prognosis non-hodgkin lymphoma patients, including those who are resistant to or relapsing after chimeric antigen receptor T-Cell (CAR-T) Therapies, and Is active in treatment through multiple lines. Blood 2019, 134, 6. [CrossRef]

114. Albertini, M.R.; Yang, R.K.; Ranheim, E.A.; Hank, J.A.; Zuleger, C.L.; Weber, S.; Neuman, H.; Hartig, G.; Weigel, T.; Mahvi, D.; et al. Pilot trial of the hu14.18-IL2 immunocytokine in patients with completely resectable recurrent stage III or stage IV melanoma. Cancer Immunol. Immunother. 2018, 67, 1647-1658. [CrossRef] [PubMed]

115. Ansell, S.M.; Lin, Y. Immunotherapy of lymphomas. J. Clin. Investig. 2020, 130, 1576-1585. [CrossRef] [PubMed]

116. Levy, R.; Ganjoo, K.N.; Leonard, J.P.; Vose, J.M.; Flinn, I.W.; Ambinder, R.F.; Connors, J.M.; Berinstein, N.L.; Belch, A.R.; Bartlett, N.L.; et al. Active idiotypic vaccination versus control immunotherapy for follicular lymphoma. J. Clin. Oncol. Am. Soc. Clin. Oncol. J. 2014, 32, 1797-1803. [CrossRef] [PubMed] 
117. Freedman, A.; Neelapu, S.S.; Nichols, C.; Robertson, M.J.; Djulbegovic, B.; Winter, J.N.; Bender, J.F.; Gold, D.P.; Ghalie, R.G.; Stewart, M.E.; et al. Placebo-controlled phase III trial of patient-specific immunotherapy with mitumprotimut-T and granulocyte-macrophage colony-stimulating factor after rituximab in patients with follicular lymphoma. J. Clin. Oncol. Am. Soc. Clin. Oncol. J. 2009, 27, 3036-3043. [CrossRef] [PubMed]

118. Thomas, S.K.; Cha, S.-C.; Smith, D.L.; Kim, K.H.; Parshottam, S.R.; Rao, S.; Popescu, M.; Lee, V.Y.; Neelapu, S.S.; Kwak, L.W. Phase I study of an active immunotherapy for asymptomatic phase Lymphoplasmacytic lymphoma with DNA vaccines encoding antigen-chemokine fusion: Study protocol. BMC Cancer 2018, 18, 187. [CrossRef]

119. Meleshko, A.N.; Petrovskaya, N.A.; Savelyeva, N.; Vashkevich, K.P.; Doronina, S.N.; Sachivko, N.V. Phase I clinical trial of idiotypic DNA vaccine administered as a complex with polyethylenimine to patients with B-cell lymphoma. Hum. Vaccines Immunother. 2017, 13, 1-6. [CrossRef]

120. Hsu, F.J.; Benike, C.; Fagnoni, F.; Liles, T.M.; Czerwinski, D.; Taidi, B.; Engleman, E.G.; Levy, R. Vaccination of patients with B-cell lymphoma using autologous antigen-pulsed dendritic cells. Nat. Med. 1996, 2, 52-58. [CrossRef]

121. Timmerman, J.M.; Czerwinski, D.K.; Davis, T.A.; Hsu, F.J.; Benike, C.; Hao, Z.M.; Taidi, B.; Rajapaksa, R.; Caspar, C.B.; Okada, C.Y.; et al. Idiotype-pulsed dendritic cell vaccination for B-cell lymphoma: Clinical and immune responses in 35 patients. Blood 2002, 99, 1517-1526. [CrossRef]

122. Di Nicola, M.; Zappasodi, R.; Carlo-Stella, C.; Mortarini, R.; Pupa, S.M.; Magni, M.; Devizzi, L.; Matteucci, P.; Baldassari, P.; Ravagnani, F.; et al. Vaccination with autologous tumor-loaded dendritic cells induces clinical and immunologic responses in indolent B-cell lymphoma patients with relapsed and measurable disease: A pilot study. Blood 2009, 113, 18-27. [CrossRef]

123. Hammerich, L.; Marron, T.U.; Upadhyay, R.; Svensson-Arvelund, J.; Dhainaut, M.; Hussein, S.; Zhan, Y.; Ostrowski, D.; Yellin, M.; Marsh, H.; et al. Systemic clinical tumor regressions and potentiation of PD1 blockade with in situ vaccination. Nat. Med. 2019, 25, 814-824. [CrossRef] [PubMed]

124. Tuscano, J.M.; Maverakis, E.; Groshen, S.; Tsao-Wei, D.; Luxardi, G.; Merleev, A.A.; Beaven, A.; DiPersio, J.F.; Popplewell, L.; Chen, R.; et al. A Phase I Study of the Combination of Rituximab and Ipilimumab in Patients with Relapsed/Refractory B-Cell Lymphoma. Clin. Cancer Res. 2019, 25, 7004-7013. [CrossRef]

125. Neelapu, S.S.; Locke, F.L.; Bartlett, N.L.; Lekakis, L.J.; Miklos, D.B.; Jacobson, C.A.; Braunschweig, I.; Oluwole, O.O.; Siddiqi, T.; Lin, Y.; et al. Axicabtagene ciloleucel CAR T-Cell therapy in refractory large B-Cell Lymphoma. N. Engl. J. Med. 2017, 377, 2531-2544. [CrossRef]

126. Boyiadzis, M.M.; Dhodapkar, M.V.; Brentjens, R.J.; Kochenderfer, J.N.; Neelapu, S.S.; Maus, M.V.; Porter, D.L.; Maloney, D.G.; Grupp, S.A.; Mackall, C.L.; et al. Chimeric antigen receptor (CAR) T therapies for the treatment of hematologic malignancies: Clinical perspective and significance. J. Immunother. Cancer 2018, 6, 137. [CrossRef] [PubMed]

127. Hay, K.A.; Turtle, C.J. Chimeric Antigen Receptor (CAR) T Cells: Lessons learned from targeting of CD19 in B-Cell malignancies. Drugs 2017, 77, 237-245. [CrossRef] [PubMed]

128. Schuster, S.J.; Bishop, M.R.; Tam, C.S.; Waller, E.K.; Borchmann, P.; McGuirk, J.P.; Jäger, U.; Jaglowski, S.; Andreadis, C.; Westin, J.R.; et al. Tisagenlecleucel in adult relapsed or refractory diffuse large B-Cell Lymphoma. N. Engl. J. Med. 2019, 380, 45-56. [CrossRef] [PubMed]

129. Bao, F.; Wan, W.; He, T.; Qi, F.; Liu, G.; Hu, K.; Lu, X.-A.; Yang, P.; Dong, F.; Wang, J.; et al. Autologous $\mathrm{CD} 19$-directed chimeric antigen receptor- $\mathrm{T}$ cell is an effective and safe treatment to refractory or relapsed diffuse large B-cell lymphoma. Cancer Gene Ther. 2019, 26, 248-255. [CrossRef]

130. Cao, Y.; Lu, W.; Sun, R.; Jin, X.; Cheng, L.; He, X.; Wang, L.; Yuan, T.; Lyu, C.; Zhao, M. Anti-CD19 chimeric antigen receptor $\mathrm{T}$ Cells in combination with nivolumab are safe and effective against relapsed/refractory B-Cell non-hodgkin lymphoma. Front. Oncol. 2019, 9, 767. [CrossRef]

131. Nair, R.; Neelapu, S.S. The promise of CAR T-cell therapy in aggressive B-cell lymphoma. Best Pract. Res. Clin. Haematol. 2018, 31, 293-298. [CrossRef]

(C) 2020 by the authors. Licensee MDPI, Basel, Switzerland. This article is an open access article distributed under the terms and conditions of the Creative Commons Attribution (CC BY) license (http://creativecommons.org/licenses/by/4.0/). 